\title{
Research on Accessibility and Equity of Urban Transport Based on Multisource Big Data
}

\author{
Fei Shi \\ Nanjing University, Nanjing, China \\ Correspondence should be addressed to Fei Shi; shifei@nju.edu.cn
}

Received 2 September 2021; Revised 15 October 2021; Accepted 18 October 2021; Published 10 November 2021

Academic Editor: Chansung Kim

Copyright (c) 2021 Fei Shi. This is an open access article distributed under the Creative Commons Attribution License, which permits unrestricted use, distribution, and reproduction in any medium, provided the original work is properly cited.

\begin{abstract}
Daily travel is an important means for everyone to obtain the right to development. With the development of the economy and the progress of the times, the equalization of public infrastructure has become an important concern. The accessibility and fairness of transportation have become a hot topic of research in various fields. To promote transport equity and formulate more reasonable transport planning and policies, this paper takes the Kunshan city as the research object, based on the mobile phone signaling data and the travel time consumption data from the application programming interface (API) of Gaode Map, using weighted average accessibility and the Theil index to investigate the accessibility and equity of public transport and car traffic in the Kunshan city. The study found that the accessibility of public transport is lower than that of car transport in the same research unit, but the equity of public transport is better than that of car transport, that is, the public transport is fair and the efficiency is neglected. In the same mode of transportation, equity presents a high four-week low distribution in the central urban area, and the spatial equity difference is mainly caused by the difference in accessibility levels between cell units. According to the research conclusions, it is recommended that Kunshan further optimize the spatial layout of public transportation infrastructure and adopt measures such as bus speed increase to achieve equity and efficiency and improve the competitiveness of public transportation.
\end{abstract}

\section{Introduction}

To solve the urban traffic problems and promote the sustainable development of the city, it is necessary to formulate reasonable traffic policies to ensure the benign operation of the urban traffic system. New York City released the One New York Plan for a Strong and Just City (2014-2040) in 2015, which sets out a vision for a fair and just city [1]. The City of London released the London Plan in 2015, which set out its vision for 2036 to provide equal life opportunities for all [2]. In October 2016, the UN-Habitat III Conference took up sustainable development as its theme, discussing and signing the New Urban Agenda. It sets a new global standard for sustainable development in cities around the world, which refers to providing basic services for all citizens and ensuring equal opportunities for citizens without discrimination. In 2019, the State Council of the Central Committee of the Communist Party of China issued the "Outline for the Construction of a Strong Transportation State," which proposes a green mobility initiative and advocates the concept of green and low-carbon mobility, and public transport is the main direction of future urban transport development. What's more, Chinese leader Xi Jinping has spoken of China's unswerving commitment to common prosperity. So it is particularly important to ensure the accessibility and fairness of public transport. The "Public Transport 1.5 Strategy" proposed by Shenzhen in 2015 has become a reasonable reference target for public transport construction in China. The total time spent on public transport, including walking to the bus stop, waiting for the bus, taking the bus, and walking to the destination, is within 1.5 times that of a car.

Accessibility in this paper refers to the accessibility of two different modes of transport: public transport and cars. Our prime objective is to evaluate the accessibility of different transportation modes by using multisource big data to measure the unfairness of different transportation modes. This research has two purposes. First, we aim to promote the 
fairness of transportation modes. If we take measures to reduce the cost of transportation, people will prefer to travel by bus rather than by car. The second is to promote regional equity by matching the supply and demand through the rational distribution of regional traffic resources. Using the Kunshan city as an example, we first simulate its per capita travel time consumption and obtain the accessibility of public transportation and car transportation modes according to population weighting. Secondly, we select the Theil index to deeply analyze the equity differences between different spatial levels and different transportation modes in the Kunshan city. The results provide a scientific basis for policymakers, as well as offer references for analyzing accessibility by using multisource big data.

This paper is organized as follows: Section 1 reviews related studies on the concept and methods of traffic accessibility, traffic fairness, and Theil index. Section 2 illustrates the source and processing method of multisource big data. Section 3 presents the results of the data analysis on accessibility, traffic fairness, and Theil index in Kunshan. Section 4 provides some suggestions for Kunshan and concludes with the advantages of big data for measuring accessibility.

\section{Review}

2.1. Concept and Research Perspectives of Traffic Accessibility. Accessibility has a rich and flexible connotation and is broadly defined as the ability of people to use alternative modes of transport to reach necessary or desired activities [3]. Accessibility can also be understood as the ease of access to more available opportunities and the inherent impedance used to travel from origin to destination, often measured in terms of the impedance of jobs, distances, or units of time [4]. Due to different research perspectives, scholars of different disciplines have different understandings of the concept of accessibility. Accessibility research can be divided into individual-based, utility-based, infrastructure-based, and location-based accessibility studies: Individual-based accessibility studies analyze accessibility at the individual level, such as the number of activities a person can engage in at a given time. Such measures are based on spatiotemporal geography and are used to measure environmental constraints on an individual's freedom of movement; utilitybased accessibility studies use economic benefits as a measure to calculate the economic benefits of travel for each individual; infrastructure-based accessibility studies analyze the performance or level of service of transport infrastructure, observe congestion on road networks, or calculate average travel speeds; and location-based accessibility studies usually analyze the accessibility of a location at a macro level [5-14]. In this paper, accessibility focuses more on the connections and interactions between spaces, that is, location-based spatial accessibility.

2.2. Analytical Approach to Traffic Accessibility. Based on the review of the progress of traffic accessibility research, accessibility analysis methods can be specifically divided into the following seven types (Table 1): (i) Buffer-based accessibility of public transport stops is based on the supply of public transport services. Buffer zones can be delineated by network analysis method [15] or constructed by facility points [16] to measure the service capacity of public transport stations. But without considering the process of transit mode, the evaluation results are comprehensive enough.

(ii) The surface accessibility of the public transport based on the supply and demand model considers the supply capacity of development opportunities, the demand degree of people's demand development, the choice of travel mode, and road network, which can roughly reflect the employment accessibility of urban public transport but does not consider the actual bus travel routes [17].

(iii) The accessibility index of public transport network based on the network analysis method is constructed by ArcGis to measure the accessibility to land use destinations by public transport. Considering the actual bus travel process, the research unit is relatively delicate, which can accurately calculate the actual accessibility of public transport travel. However, its effect is poor in areas with small bus network density [18, 19].

(iv) The accessibility of public transportation based on grid method cost using timeline for the analysis of space in a little bus accessibility, an accurate calculation of two-dimensional space accessibility, but limited to raster data, unable to simulate the real public transit, such as dock station [20-22].

(v) Public transport accessibility based on the integration of cost raster and network analysis uses the cost raster method to calculate travel costs during walking and network analysis to calculate travel costs during public transport operation. Considering the impedance of bus running and walking, the accuracy of public transport accessibility calculation is improved $[23,24]$.

(vi) High-accuracy accessibility of public transport based on a high-performance graphical database can accurately simulate the public transport interchange process by considering the whole process of travel, a building-to-building study of public transport accessibility. But the practical application of this method is limited by a large amount of data and the difficulty of access $[25,26]$.

(vii) The high-precision accessibility of public transport based on open map APIs can consider the whole process of travel through batch crawling and application of online map spatiotemporal big data, and the data used have the characteristics of high timeliness and high authenticity. Many scholars have done extensive research on route planning tools based on the Google Maps API (application programming interface). Boisjoly et al. [27] set the departure time to 7 am to obtain the cost of travel during peak hours 
TABLE 1: Summary of public transport accessibility methods.

\begin{tabular}{|c|c|c|c|c|c|}
\hline Name & Research data & $\begin{array}{l}\text { Research } \\
\text { accuracy }\end{array}$ & $\begin{array}{l}\text { Individuals } \\
\text { studied }\end{array}$ & Advantages & Disadvantages \\
\hline $\begin{array}{l}\text { Buffer-based } \\
\text { accessibility of public } \\
\text { transport stops }\end{array}$ & $\begin{array}{l}\text { Road network data and } \\
\text { public transport station } \\
\text { data }\end{array}$ & $\begin{array}{l}\text { Range of } \\
\text { walking } \\
\text { trips }\end{array}$ & Every bus stop & $\begin{array}{l}\text { The actual travel network } \\
\text { is considered } \\
\text { It is easy to operate }\end{array}$ & $\begin{array}{l}\text { Areas not covered are by } \\
\text { default unreachable by } \\
\text { public transport } \\
\text { No consideration is given to } \\
\text { actual travel conditions }\end{array}$ \\
\hline $\begin{array}{l}\text { Face-to-face } \\
\text { accessibility of public } \\
\text { transport based on } \\
\text { supply and demand } \\
\text { models }\end{array}$ & $\begin{array}{l}\text { Road network data, public } \\
\text { transport stop and line } \\
\text { network data, jobs data, } \\
\text { population data, and } \\
\text { traffic analysis areas }\end{array}$ & $\begin{array}{c}\text { Traffic } \\
\text { analysis } \\
\text { zone (TAZ) }\end{array}$ & $\begin{array}{l}\text { The entire } \\
\text { study area }\end{array}$ & $\begin{array}{l}\text { It can reasonably reflect } \\
\text { the spatial variability of } \\
\text { employment supply and } \\
\text { demand, reflecting the } \\
\text { temporal and spatial } \\
\text { variability in the level of } \\
\text { service of the transport } \\
\text { network }\end{array}$ & $\begin{array}{l}\text { The values of the } \\
\text { accessibility indicators are } \\
\text { not scaled and have no } \\
\text { specific practical meaning }\end{array}$ \\
\hline $\begin{array}{l}\text { Public transport } \\
\text { network accessibility } \\
\text { based on network } \\
\text { analysis }\end{array}$ & $\begin{array}{l}\text { Road network data, public } \\
\text { transport stop, and line } \\
\text { network data }\end{array}$ & $\begin{array}{l}\text { Dividing } \\
\text { the study } \\
\text { area into } \\
\text { grids }\end{array}$ & $\begin{array}{l}\text { The entire } \\
\text { study area }\end{array}$ & $\begin{array}{l}\text { It fully reflects the } \\
\text { network characteristics of } \\
\text { the public transport } \\
\text { network and can be used } \\
\text { to compare the spatial } \\
\text { distribution } \\
\text { characteristics of the } \\
\text { network in different cities }\end{array}$ & $\begin{array}{l}\text { No consideration is given to } \\
\text { the actual need to travel }\end{array}$ \\
\hline
\end{tabular}

\begin{tabular}{|c|c|c|c|c|c|}
\hline $\begin{array}{l}\text { Public transport } \\
\text { accessibility based on } \\
\text { a cost-grid approach }\end{array}$ & $\begin{array}{l}\text { Data on the spatial } \\
\text { characteristics of the } \\
\text { study area (mountains, } \\
\text { water bodies, green } \\
\text { spaces, etc.), data on the } \\
\text { road network, data on } \\
\text { public transport stops and } \\
\text { lines, and data on jobs }\end{array}$ & $\begin{array}{l}\text { Dividing } \\
\text { the study } \\
\text { area into } \\
\text { raster }\end{array}$ & $\begin{array}{l}\text { One point- } \\
\text { based } \\
\text { accessibility } \\
\text { study }\end{array}$ & $\begin{array}{l}\text { It is mainly used to } \\
\text { present the accessibility of } \\
\text { points and calculate the } \\
\text { cost of travel to points and } \\
\text { the availability of jobs or } \\
\text { service levels }\end{array}$ & $\begin{array}{l}\text { The requirements for raw } \\
\text { data are high; the } \\
\text { calculation process is } \\
\text { complex and difficult; and } \\
\text { the accessibility varies with } \\
\text { the given range }\end{array}$ \\
\hline $\begin{array}{l}\text { Public transport } \\
\text { accessibility based on } \\
\text { an integrated } \\
\text { approach to cost } \\
\text { raster and network } \\
\text { analysis }\end{array}$ & $\begin{array}{l}\text { Data on the spatial } \\
\text { characteristics of the } \\
\text { study area (mountains, } \\
\text { water bodies, green } \\
\text { spaces, etc.), data on the } \\
\text { road network, data on } \\
\text { public transport stops and } \\
\text { lines, and data on jobs }\end{array}$ & $\begin{array}{l}\text { Dividing } \\
\text { the study } \\
\text { area into } \\
\text { raster }\end{array}$ & $\begin{array}{l}\text { One point- } \\
\text { based } \\
\text { accessibility }\end{array}$ & $\begin{array}{l}\text { A network analysis based } \\
\text { on the bus network and a } \\
\text { walking cost calculation } \\
\text { based on a cost-grid } \\
\text { allows a more complete } \\
\text { reach based on one point }\end{array}$ & $\begin{array}{l}\text { The requirements for raw } \\
\text { data are high; the } \\
\text { calculation process is } \\
\text { complex and difficult; it is } \\
\text { not very operational in the } \\
\text { analysis of the accessibility } \\
\text { of large areas; and the } \\
\text { accessibility of a given area } \\
\text { varies with its size }\end{array}$ \\
\hline $\begin{array}{l}\text { High-precision } \\
\text { accessibility of public } \\
\text { transport based on a } \\
\text { high-performance } \\
\text { graphics database }\end{array}$ & $\begin{array}{l}\text { Road network data, public } \\
\text { transport stop network } \\
\text { data, travel schedules, and } \\
\text { building locations }\end{array}$ & $\begin{array}{l}\text { Building to } \\
\text { building }\end{array}$ & $\begin{array}{l}\text { The entire } \\
\text { study area }\end{array}$ & $\begin{array}{l}\text { The whole process of } \\
\text { public transport travel is } \\
\text { considered }\end{array}$ & $\begin{array}{l}\text { It is computationally } \\
\text { intensive and demanding in } \\
\text { terms of data collection }\end{array}$ \\
\hline $\begin{array}{l}\text { High-accuracy } \\
\text { accessibility of public } \\
\text { transport based on } \\
\text { open map APIs }\end{array}$ & $\begin{array}{c}\text { Open map API to obtain } \\
\text { codes and start and finish } \\
\text { latitude and longitude } \\
\text { coordinates }\end{array}$ & $\begin{array}{l}\text { Building to } \\
\text { building }\end{array}$ & $\begin{array}{l}\text { The entire } \\
\text { study area }\end{array}$ & $\begin{array}{l}\text { The whole process of } \\
\text { public transport travel is } \\
\text { considered, and travel } \\
\text { costs are obtained more } \\
\text { accurately }\end{array}$ & $\begin{array}{l}\text { It requires sifting and } \\
\text { processing of a large } \\
\text { amount of data crawled }\end{array}$ \\
\hline
\end{tabular}

and showed that people living in areas with low public transport accessibility are mostly low-income people. Moreno-Monroy et al. [28] collected the latitude and longitude of schools and students' residences, entered the information into Google Maps, and selected different modes of travel for route planning to obtain information on travel times, costs, and specific routes to determine the accessibility of students to school. Other scholars have studied the relationship between accessibility and carbon emissions, and the accessibility calculation was based on the data collection of various open map APIs such as Google Maps, Bing Maps, and Open Street Maps to compare the cost of travel, and finally, the different travel modes have been correlated with the carbon emissions of travel [29]. Chen et al. have designed city accessibility analysis software based on open map APIs to create isochrones through trip point determination [30]. 
2.3. Transport Accessibility and Transport Equity. Accessibility, as an indicator of the level of urban transport services, is an important medium for measuring travel costs, social linkages, policy evaluation, and regional equilibrium and is inherently equitable. Many scholars have analyzed and evaluated accessibility in terms of employment [31], distribution of facilities [32], transport modes [33], and transport policies [34] to reflect the equity of urban transport. The accessibility of different transport modes is different, and minimizing the difference in social benefits between different modes can solve the problem of fairness in urban transport; the accessibility of different regions also differs, and reasonable transport planning can solve the problem of fairness in regional transport resources by distributing transport resources in a balanced manner in the region; the transport modes of different groups are different, and the travel costs are also different. Different groups have different modes of transport and different costs of travel. By implementing policies to protect the transport rights of the disadvantaged groups, we can ensure that different sectors of the city can enjoy the various services and facilities or travel rights fairly and promote social equity. Therefore, accessibility and equity are closely related.

\subsection{Concept and Classification of Transport Equity.} Equity refers to the appropriate distribution of the impact effects (e.g., benefits and costs) of a policy or measure [35]. In the field of transportation, Litman analyzed the connotation of transportation equity systematically for the first time and divided transportation equity into two categories: horizontal equity and vertical equity [36]. Horizontal equity refers to the concern that everyone enjoys a fair opportunity to pay the cost of travel without considering the variability of human needs and travel ability, that is, absolute equity, the core of which is to provide services to the largest number of users [37]. Lv studied the fairness of transportation based on the perspective of horizontal equity, arguing that travelers should have equal accessibility [38]. Vertical equity refers to paying attention to the income differences and behavioral capabilities of different social classes and groups and advocates that transport services should be favored to the disadvantaged groups to protect them from bearing excessive extra costs, the core of which is to provide services to the people who need them most [39]. Based on the perspective of vertical equity, Yang studied the relative transport equity of different members of society in terms of what they pay and deserve [40]. In addition, other scholars have studied the equity of transport modes from the perspective of competition between different transport modes [41], the equity of transport infrastructure layout from a spatial perspective [42], and the equity of transport planning and transport investment by combining transport big data [43].

2.5. Measurement of Transport Equity. In the field of transportation, fairness can be understood as whether the benefits of various transportation facilities are equally distributed in bringing benefits to different social interest groups, so Yang Lang et al. constructed a fairness evaluation model $[44,45]$ from the assumption that the amount of distributed benefits conforms to the entropy distribution and studied the fairness of road project construction investment; Chen et al. [46], on the other hand, took into account the individual transportation travel in Li et al. [47] and proposed a graph-based public transport connectivity (PTC) index to measure the accessibility and equity of individual buildings for evaluating MRT services in Singapore.

Accessibility, which to a certain extent reflects equity, can be divided into three categories according to the mode of analysis: spatial barrier analysis, opportunity accumulation analysis, and spatial interaction analysis. Spatial barrier models evaluate the equity of the transport network itself in terms of differences in the ease of travel in a neighborhood; opportunity accumulation models measure equity between individuals in terms of differences in the number of services or resources that people receive in equilibrium; and spatial interaction models reflect equity in terms of the relationship between population size distribution and the spatial distribution of resources [48]. While accessibility values can provide a rough indication of equity to some extent, more specific equity evaluation indicators need to be further explored.

Equity in economics is more concerned with the differences between income and distribution, with the Gini coefficient, the Lorenz curve, and the Theil entropy index all being indicators of income disparity in economics. The Lorenz curve is a linear relationship between the cumulative percentage of the population and the cumulative percentage of income in a country or region; the Gini coefficient is an indicator of equality of distribution based on the logic of the Lorenz curve and is the quotient of the area between the actual income and the absolute equity line in the Lorenz curve and the area below the absolute equality line. Wang Qingyun et al. first introduced the Gini coefficient and the Lorenz curve into the field of transport fairness evaluation [49], after which $\mathrm{Wu}$ Maolin and Cao Kai et al. further conducted an in-depth empirical analysis using the Gini coefficient to study the issue of transport fairness in Zibo City [50]. The Theil index is a measure of income disparity or inequality between individuals or regions, originally proposed by Theil based on the information entropy theory, and few relevant articles use the Theil index to study traffic accessibility equity.

2.6. Research and Application of the Theil Index. At present, the Theil index is more frequently used in the study of regional economic disparities. Niu studied the economic disparities among the three major economic zones in the west, central, and southeast of Gansu Province based on the Ter Index and provided a reference for the reasonable industrial layout of Gansu Province [51]; Shi used the Theil index indicator when studying the unevenness of social security expenditure in less developed regions in the west, finding that the overall disparity is shrinking and intraregional differences are the main factor constituting the overall difference and made suggestions for the coordinated development of social security resource allocation across regions in Xinjiang [52]. 
TABLE 2: Statistical table of study area divisions.

\begin{tabular}{lcc}
\hline District & Number of transport zones & Number of base station units \\
\hline Waterfront old town area & 22 & 427 \\
Eastern vice city & 12 & 452 \\
Yangcheng lake area & 7 & 207 \\
Northern new town & 7 & 215 \\
Central city & 15 & 885 \\
Western vice city & 9 & 370 \\
Southern new town & 6 & 248 \\
Huaqiao business area & 7 & 225 \\
Total & 85 & 3029 \\
\hline
\end{tabular}

In addition to its application in the field of economics, the Theil index is also more frequently used in studies on the equity of public service facilities such as health care resources. In their study of equity in the allocation of health resources in Chongqing, Lai et al. first used the Gini coefficient to analyze overall inequity and then used the Theil index to determine that intra-regional differences were the main cause of inequity [53]; Liu used the Theil index to assess the level of equalization of health services in urban and rural areas [54]; Sun et al. used the Theil index to study the equity of health resource allocation in southern, central, and northern Jiangsu Province [55]; and Lv used the Theil index to study the spatial imbalance of transport infrastructure in the New Silk Road Economic Belt [56].

In the field of transportation, the Theil index is mostly used as an indicator to assess the equity of road network design, for example, Bruno Santos combined three indices of accessibility, Gini coefficient, and Theil index to study the equity of road network design [57], and Feng et al. [58] used the GINI coefficient, Theil index, mean log deviation, relative mean deviation, coefficient of variation, and Atkinson index as six representative indicators to construct an accessibilitybased transport equity-type evaluation model, which provides various options for road network design decisions. This paper attempts to evaluate urban transport equity using the Theil index of public transport and car accessibility, which is innovative and also has policy and spatial guidance implications for cities to improve urban transport equity.

\section{Materials and Methods}

3.1. Study Area. This paper takes the Kunshan city as an example. Based on the Kunshan City Master Plan (2009-2030), the city area is firstly divided into 8 districts: the central city, the eastern subcity, the western subcity, the northern new city, the southern new city, the Huaqiao Business Area, Yangcheng Lake area, and the Water Town area; then each district is divided according to traffic zones, for a total of 85 transport zones; finally, the Tyson polygon was divided into 3,209 base station units based on the base stations within the traffic region as the smallest unit of study (Table 2; Figure 1).

3.2. Data Acquisition. The main data for the study consisted of two parts: residential travel data based on mobile phone signaling data and traffic accessibility data based on travel time consumption. The mobile phone signaling data was obtained through the mobile company's base station record information, and the traffic accessibility data was obtained using the Gaode Map open-source data platform.

\subsubsection{Acquisition and Processing of Mobile Phone Signaling}

Data. The mobile phone signaling data in this study was a series of information records that record the interaction between an anonymous ID and its base station (Table 3). When the user was within the service range of the nearest base station, the mobile phone signal would interact with the base station, and the time and location of the interaction would be recorded by the base station. When the user moved to the service range of another base station, the mobile phone would disconnect from the previous base station and interact with the nearest base station. Accordingly, when the recorded base station information changed, the user was considered to have moved. However, a user's movement did not represent a valid trip for the user. If one interactive base station switch was considered as a trip, the user's real trip would be treated as a series of short-distance trips.

To specifically discern the user's movement status, this study drew on the approach of Demissie et al. [59] to identify each trip of the user by applying the following processing to the mobile phone data:

(i) Sorting the mobile phone data of user $x$ throughout the day by time series $u x=(u x(1), u x(2), \ldots, u x(N))$.

(ii) Grouping the time date according to the base station number and dividing consecutive time series of interactions between the same base stations into the same group, $u x(k)=(t x(k), l x(k)) . T x(k)$ and $L x(k)$, respectively, represented the interaction time and base station location of the KTH group of user X.

(iii) Determining the character of the base station. For the $k$-th group of data, the time of the first interaction with this group of base stations was recorded as FTk, and the time of the last interaction was LTk, then the duration of the stay at this place Durationk $=\mathrm{LTk}-$ FTk. If Durationk $<30$ min, then this base station was a passing point, and vice versa, this point was a stay.

(iv) Aggregating the travel data of all users processed by the above method to obtain travel statistics based on mobile phone signaling data. 


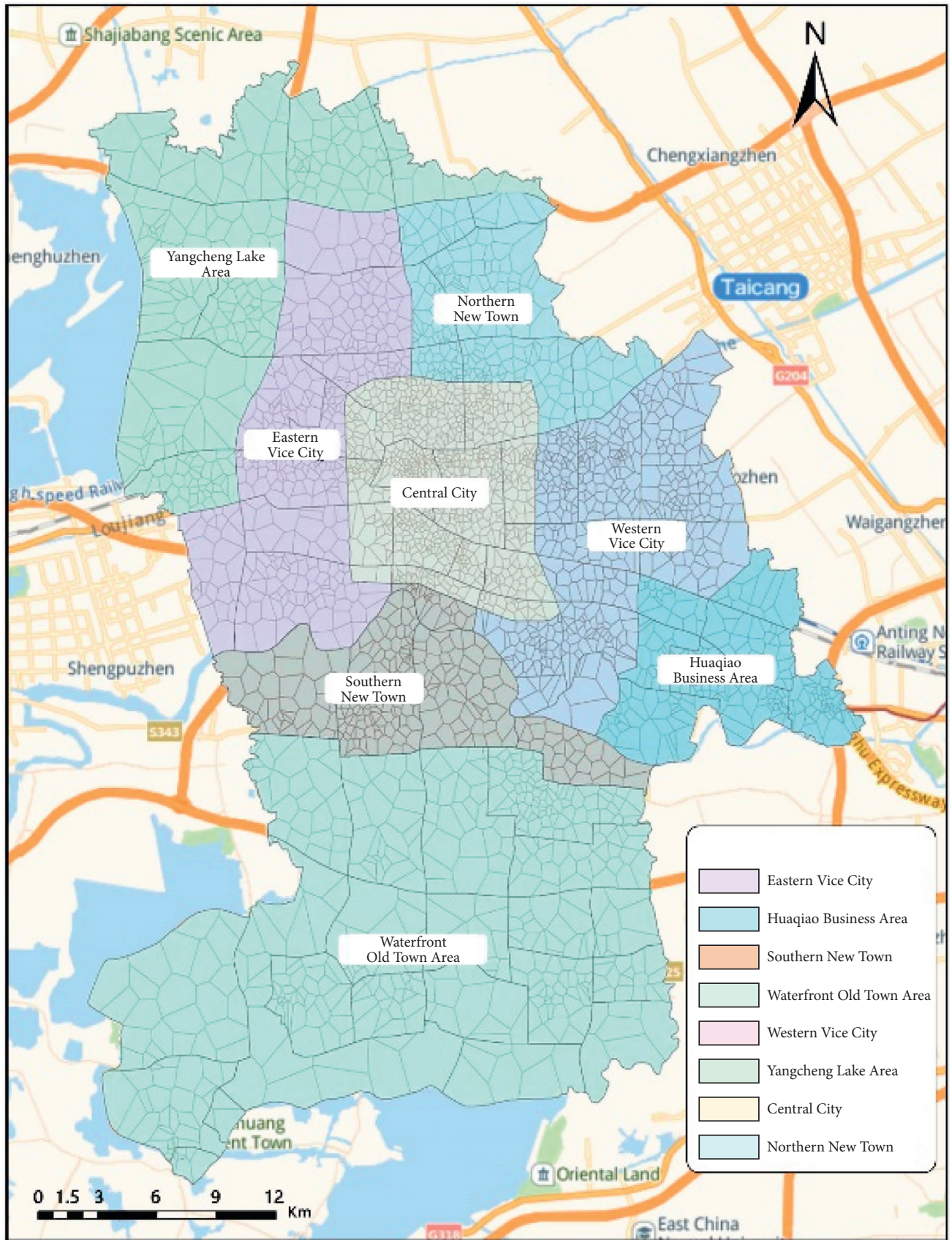

Figure 1: Division of the Kunshan study unit.

TABle 3: A sample record from mobile phone signaling.

\begin{tabular}{lcccccc}
\hline Event data & Event type & Imsi & Lac & Cell tower ID & Lon & Lat \\
\hline 20170107 & 33 & 8178 & 20490 & 23087493 & 118.7994 & 118.7994 \\
20170107 & 2 & 8178 & 20490 & 23087493 & 31.02988 \\
20170107 & 18 & 8178 & 20490 & 23087493 & 118.7994 & 31.02988 \\
20170107 & 33 & 8178 & 20490 & 23087493 & 118.7994 & 31.02988 \\
\hline
\end{tabular}

The mobile phone signaling data in this study were selected from all weekdays in mid-June 2017 (Table 4). A compilation of 1097,873 valid travel samples (the average number of trips on a weekday) were collected after data processing, with each travel sample including the complete departure point and destination as well as the corresponding number of trips. 
TABLE 4: Base station location and travel population data based on cellular signaling data.

\begin{tabular}{|c|c|}
\hline Field information & Description \\
\hline ID & Anonymous user number information \\
\hline First_Time & Start time, indicating the time of the first connection to this base station \\
\hline Start_Base & Start of the base station \\
\hline Start_LNG & Start base station longitude \\
\hline Start_LAT & Start base station latitude \\
\hline Last_Time & End time, that is, the time of the last connection to this base station \\
\hline End_Base & End of the base station \\
\hline End_LNG & End of base station longitude \\
\hline End_LAT & End of base station latitude \\
\hline Duration & Dwell time, equal to the difference between the end time and the start time \\
\hline Trip_Count & Record trip count data for each OD trip \\
\hline
\end{tabular}

Table 5: Travel time consumption data based on Gaode Map API.

\begin{tabular}{lc}
\hline Field information & Description \\
\hline Starting point O number & Departure base station number \\
Longitude of starting point & Longitude in Gould coordinates \\
Starting latitude & Latitude in Gould coordinates \\
Destination $D$ number & Destination base station number \\
Longitude of destination & Longitude in Gould coordinates \\
Latitude of destination & Latitude in Gould coordinates \\
Time spent traveling by public & Time spent walking from home, time spent traveling by car, time spent walking by transfer, time spent \\
transport & traveling by car after the transfer, and time spent walking to the destination \\
Travel time consumption by car & Travel time from the departure point to the destination \\
\hline
\end{tabular}

\subsubsection{Acquisition and Results of Traffic Accessibility Data.} The travel time consumption data was obtained using the Gaode Map API (application programming interface). The travel times obtained based on this method are more accurate. On the one hand, travel path was real recommended map navigation path; on the other hand, the path selection system considering walking time during route selection, waiting time, transfer impact, and traffic jams, the final travel time obtained corresponds to the impact of various factors already converted into time costs (Table 5). Based on the processing results of the mobile phone signaling data, the morning peak travel time consumption for public transport and car traffic is crawled for each OD, using the starting and ending base stations of each travel sample as OD points.

The traditional reachability calculation method is to take the arithmetic average of all OD travel time consumptions with the same origin as the reachability of $O$ points, that is, the reachability of a particular base station cell. However, this method does not take into account the effect of the number of trips. Based on the idea of travel impedance calculated by Batty [60], this study introduced the number of trips into the base station unit reachability calculation for a weighted average to match the real situation of urban residents' travel. The specific weighted average accessibility calculation formula is as follows:

$$
A_{j}=\frac{\sum_{j, k=1}^{n} T_{j k} C_{j k}}{\sum_{k=1}^{n} C_{j k}}
$$

where (i) $A_{j}$ : notation for the overall reachability of base station unit $j$ to other base station units

(ii) $T_{j k}$ : notation for the travel time consumption of base station unit $j$ to $k$

(iii) $C_{j k}$ : notation for the number of trips from base station unit $j$ to $k$

(iv) $N$ : number of $j$ base station travel destinations

3.2.3. Calculation Model of Theil Index Based on Accessibility. The Theil index is a measure of the income gap or inequality between individuals or regions. Compared to the Gini coefficient, the Theil index is well decomposed and can be studied in spatial and time series. Spatial series can explain why inequities emerge and where they are spatially located, and time series can reflect the dynamics of inequities, with smaller values indicating greater equity. The specific formula for the decomposition of the Theil index is as follows:

$$
\begin{aligned}
T_{a} & =\sum_{i}^{I}\left(W_{i} \log \frac{W_{i}}{G_{i}}\right), \\
T_{b} & =\sum_{i}^{I} W_{i}\left(\sum_{j=1}^{I} W_{i j} \log \frac{W_{i j}}{G_{i j}}\right), \\
T_{o} & =T_{a}+T_{b},
\end{aligned}
$$

where 


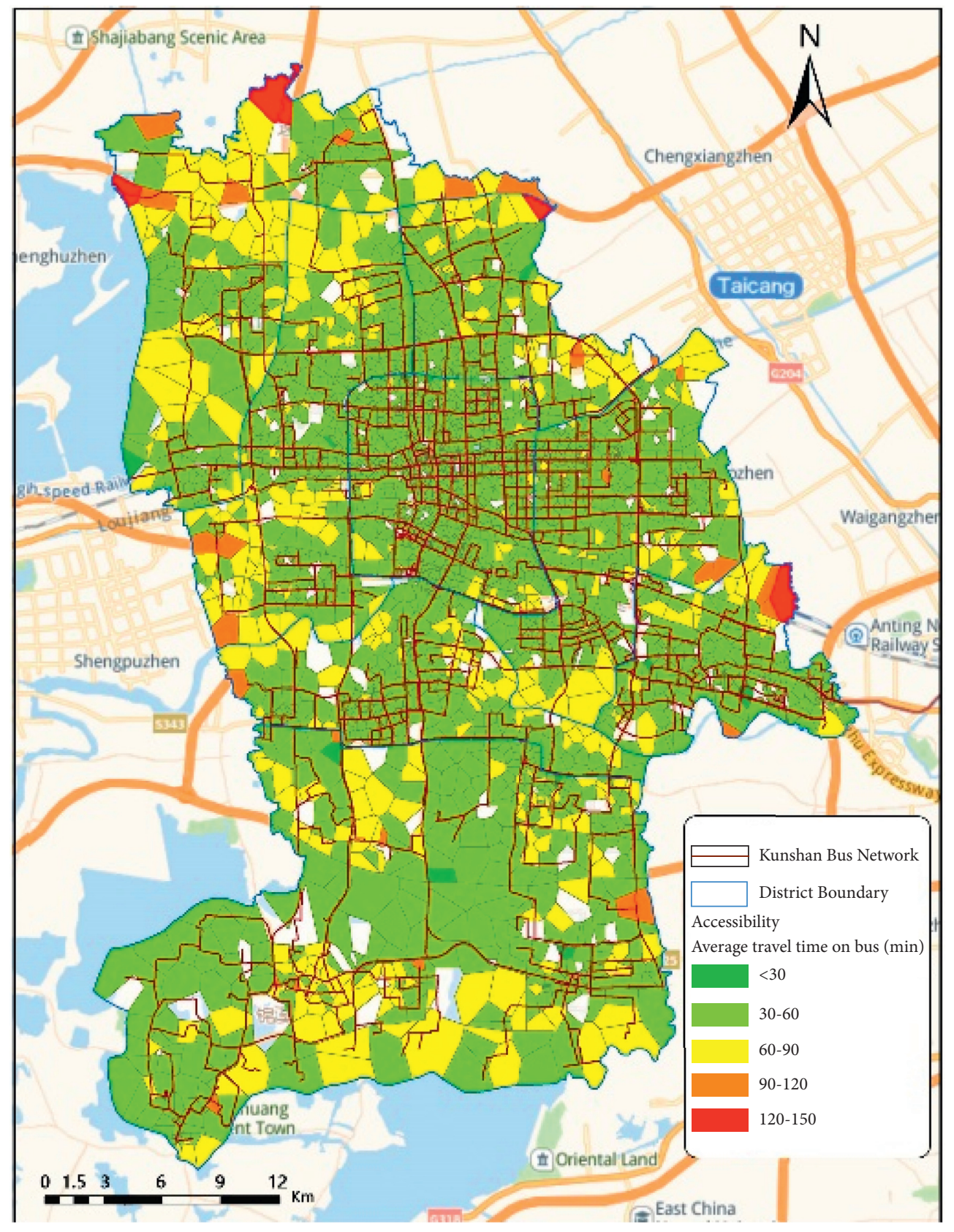

Figure 2: Public transport accessibility.

(i) $T_{o}$ : notation for the overall difference

(ii) $T_{a}$ : notation for the difference in accessibility between transport zones in the city

(iii) $T_{b}$ : notation for the difference in the accessibility of base station units within a transport zone

(iv) $I$ : notation for the number of transport zones in the district

(v) $G_{i}$ : notation for the proportion of the travel population in transportation zone $i$ to the total travel population in the district (vi) $W_{i}$ : notation for the proportion of the accessibility of transportation zone $i$ to the total accessibility of the district

(vii) $G_{i j}$ : notation for the proportion of the travel population in base station unit $j$ of transportation zone $i$ to the total travel population of transportation zone $i$

(viii) $W_{i j}$ : notation for the proportion of the accessibility of base station unit $j$ of transportation zone $i$ to the total accessibility of transportation zone $i$ 


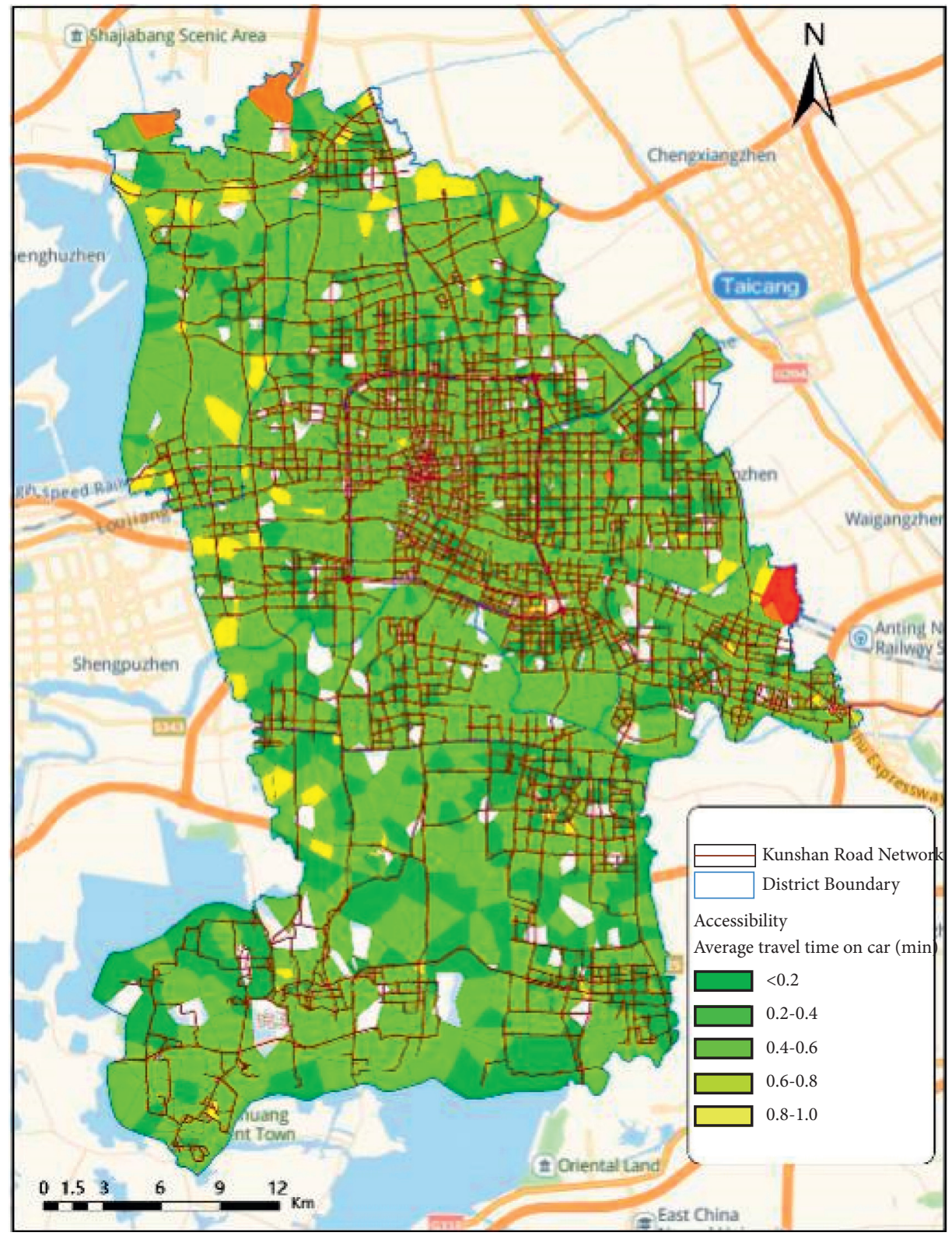

Figure 3: Minibus accessibility. The blank base station cell in the figure is the result of processing the mobile phone data after noise reduction and represents a base station cell with no valid travel data.

\section{Results and Discussions}

4.1. Results of the Accessibility Analysis Based on the Combined Model (Equation (1)). The average accessibility of public transport in Kunshan is $51 \mathrm{~min}$, and the average accessibility of cars is $15 \mathrm{~min}$. The absolute and relative values of the accessibility of public transport and cars are analyzed below.

4.1.1. Public Transport Accessibility Analysis. Public transport accessibility is heavily influenced by public transport infrastructure. So, accessibility is lower in base station units and urban peripheral areas with few transport routes, inadequate transport infrastructure, and inconvenient public transport. In terms of public transport accessibility (Figure 2), the accessibility of most areas is concentrated between $30 \mathrm{~min}$ and $90 \mathrm{~min}$. The areas with low accessibility are mainly located in the peripheral areas of the city, mainly along the eastern side of Yangcheng Lake, the northern part of Dianshan Lake, and the Tianfu National Wetland Park, where the network of public transport lines is sparse, and the coverage of public transport is insufficient compared to the central city and its surrounding areas.

4.1.2. Car Accessibility Analysis. Car accessibility is mainly influenced by the road network and is less related to the distribution and direction of the bus network. In terms of accessibility by car (Figure 3), the accessibility of most of the 
TABLe 6: Comparison of accessibility values by zone.

\begin{tabular}{lccc}
\hline Urban district & Public transport accessibility (min) & Car accessibility (min) & Reachability ratio (bus/car) \\
\hline Waterfront old town area & 0.93 & 0.23 & 3.98 \\
Eastern vice city & 0.86 & 0.23 & 3.79 \\
Yangcheng Lake area & 1.08 & 0.30 & 3.61 \\
Northern new town & 0.98 & 0.25 & 3.97 \\
Central city & 0.77 & 0.25 & 3.08 \\
Western vice city & 0.92 & 0.27 & 3.42 \\
Southern new town & 0.86 & 0.24 & 3.60 \\
Huaqiao business area & 0.88 & 0.26 & 3.46 \\
\hline
\end{tabular}

The accessibility of public transport and car is the average of the accessibility of each transport zone internal state unit.

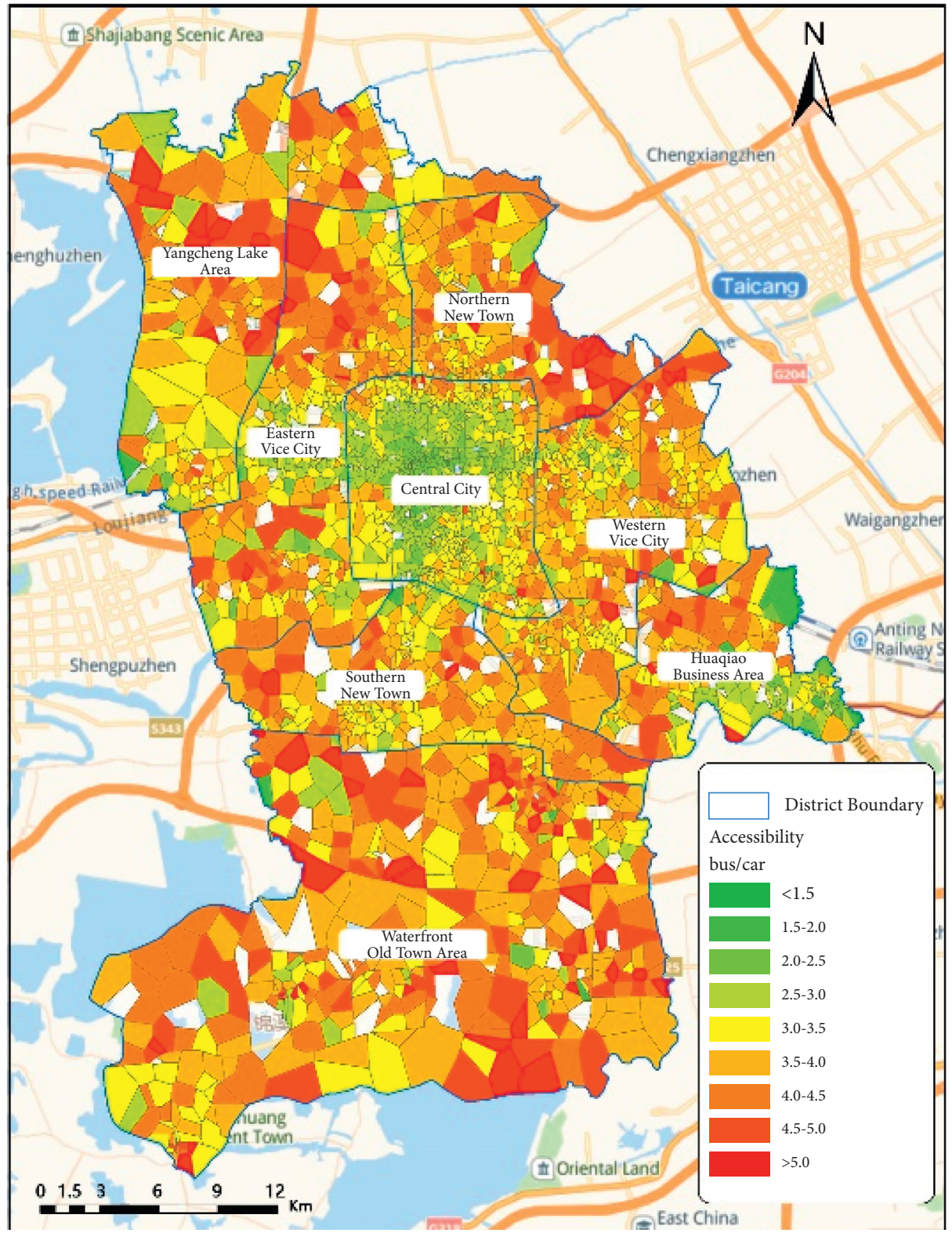

FIgURE 4: Accessibility ratios.

base stations is between $12 \mathrm{~min}$ and $24 \mathrm{~min}$, which is generally good, while the few base stations with low accessibility are located in Tianfu National Wetland Park and the northern fringe of Yangcheng Lake area, which are hardly covered by urban road network and inconvenient for car travel. 


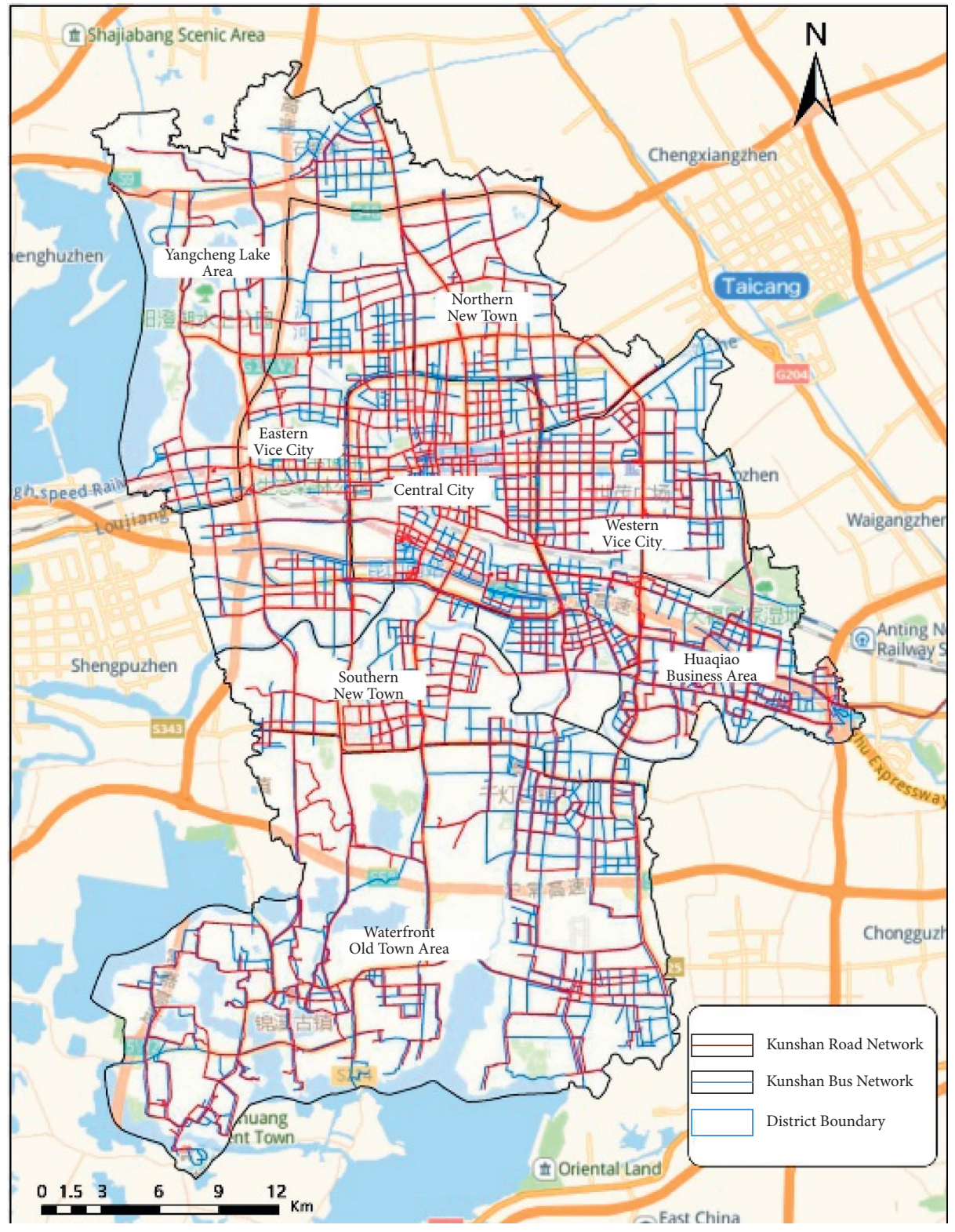

FIGURE 5: Distribution of road network and bus line network.

TABLe 7: Public transport and car accessibility in Kunshan Theil Index.

\begin{tabular}{|c|c|c|c|c|c|c|}
\hline \multirow{2}{*}{ Transport region } & \multicolumn{3}{|c|}{ Public transport } & \multicolumn{3}{|c|}{ Cars } \\
\hline & Intra-area & Inter-area & Overall & Intra-area & Inter-area & Overall \\
\hline Waterfront old town area & 0.0216 & 0.009 & 0.0306 & 0.0328 & 0.0119 & 0.0447 \\
\hline Eastern vice city & 0.0038 & 0.0145 & 0.0183 & 0.0034 & 0.0216 & 0.025 \\
\hline Yangcheng Lake area & 0.0088 & 0.0274 & 0.0362 & 0.011 & 0.0405 & 0.0515 \\
\hline Northern new town & 0.0071 & 0.012 & 0.0191 & 0.004 & 0.0219 & 0.0259 \\
\hline Central city & 0.0032 & 0.0088 & 0.012 & 0.0024 & 0.0158 & 0.0182 \\
\hline Western vice city & 0.0034 & 0.0136 & 0.017 & 0.0067 & 0.0187 & 0.0254 \\
\hline Southern new town & 0.0022 & 0.0136 & 0.0158 & 0.0003 & 0.0159 & 0.0162 \\
\hline Huaqiao business area & 0.0128 & 0.0166 & 0.0294 & 0.0168 & 0.0366 & 0.0534 \\
\hline
\end{tabular}

The area of the plot indicates the traffic zone. 


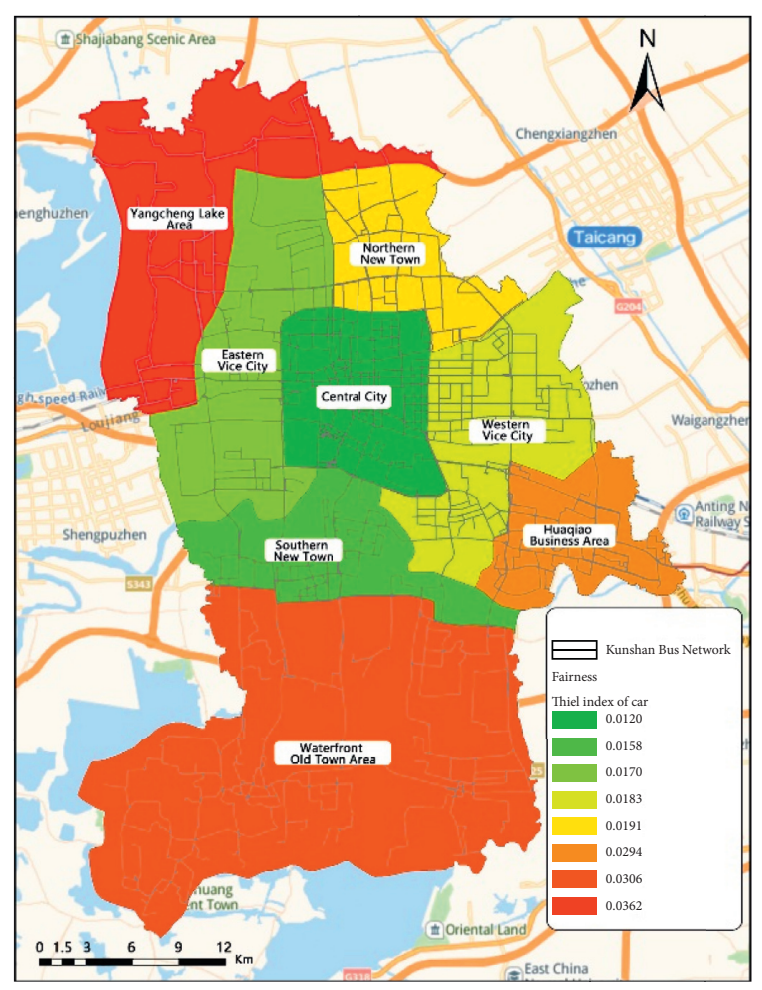

(a)

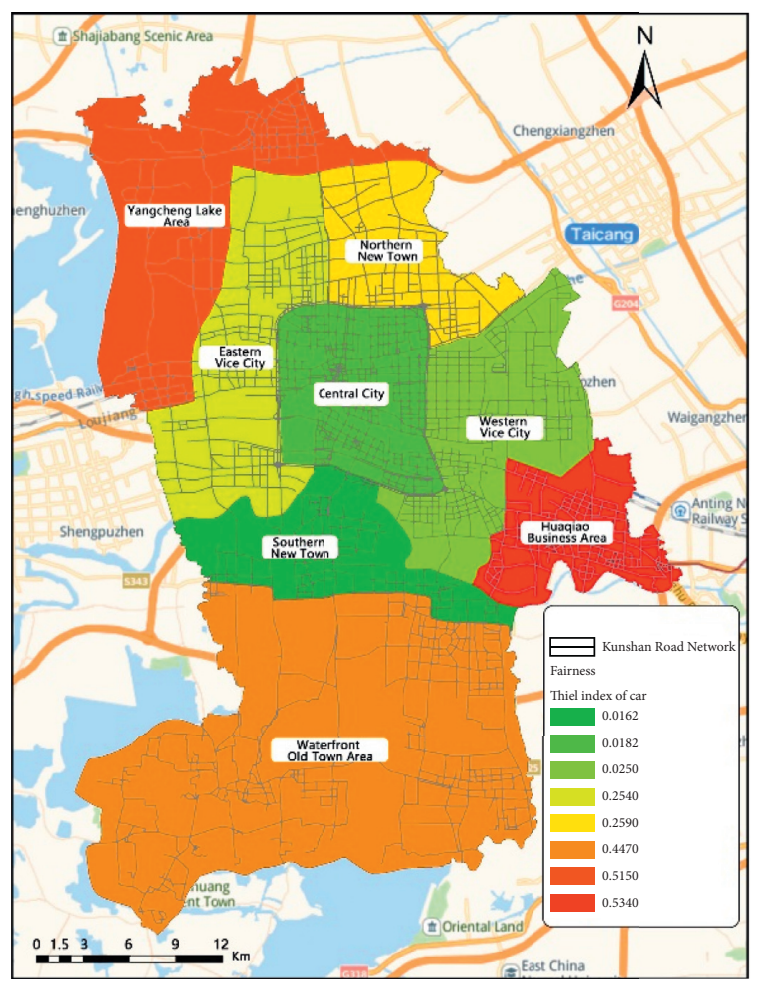

(b)

FIgURE 6: Spatial distribution of the Theil index: (a) public transport and (b) cars.

4.1.3. Analysis of the Relative Values of Accessibility in Different Ways. Table 6 presents the average travel time consumption of the different modes of transport in different spaces. From the same mode of transportation in different spaces of the average travel time, the average travel time of cars in each district is not much different; accessibility difference is small, the average travel time of buses has a certain gap; accessibility from high to low is the central urban area $>$ the southern new city $>$ the eastern vice city $>$ Huaqiao Business Area $>$ the western vice city $>$ the ancient town area of Shui Xiang $>$ Yangcheng Lake area. In terms of the average travel time of different modes of transport in the same space, the average travel time of public transport in each district is significantly higher than the travel time of cars, so the accessibility of public transport in each district is lower than the accessibility of cars overall.

In this paper, the ratio of public transportation to car traffic accessibility is used to reflect the relative priority of public transportation in each research unit. The higher the ratio, the more obvious the advantage of public transport in the region in competing with cars. It can also be used to evaluate the level of construction of public transport cities. The average ratio of public transport to car accessibility in Kunshan is 3.51, which is far lower than the value of 1.5 mentioned in Section 1, indicating that there are still great deficiencies in the construction of Kunshan public transport city, and the competitiveness level of public transport is far lower than that of car transport.

The spatial distribution of the ratio of average travel time of public transport to car accessibility (Figure 4) shows an overall low distribution in the central city and high distribution in the peripheral areas, so the competitive advantage of public transport gradually decreases from inside to outside. The road network and bus network distribution map (Figure 5) shows that the bus network in the central city covers almost every road, and the bus network in the western subcity and the southern new town, which are close to the city, also has better coverage, so the central city, the western subcity, and the southern new town have a clear competitive advantage in terms of bus network coverage.

In summary, based on the accessibility ratio and the influence of the degree of bus coverage, the competitive advantage of the bus network is central city $>$ western vice city $>$ Huaqiao business area $>$ southern new town$>$ Yangcheng Lake area $>$ eastern vice city $>$ northern new town $>$ ancient Water Town area.

4.2. Transport Equity Evaluation Based on the Theil Index. The results of the calculation of the Theil index are shown in Table 7. The smaller the value of Theil indexes, the smaller the difference in the accessibility and the fairer the traffic. Note that the Theil index of intra-area represents the difference in the accessibility of the internal base station unit of the control unit. The public transport accessibility index in the waterfront old town area is 0.0216 , which is second only to the commercial city of Huaqiao business area, indicating that the accessibility of public transport between the base station units in the waterfront old town is quite different and the development of public transport is not balanced. Note that the Theil index of inter- 


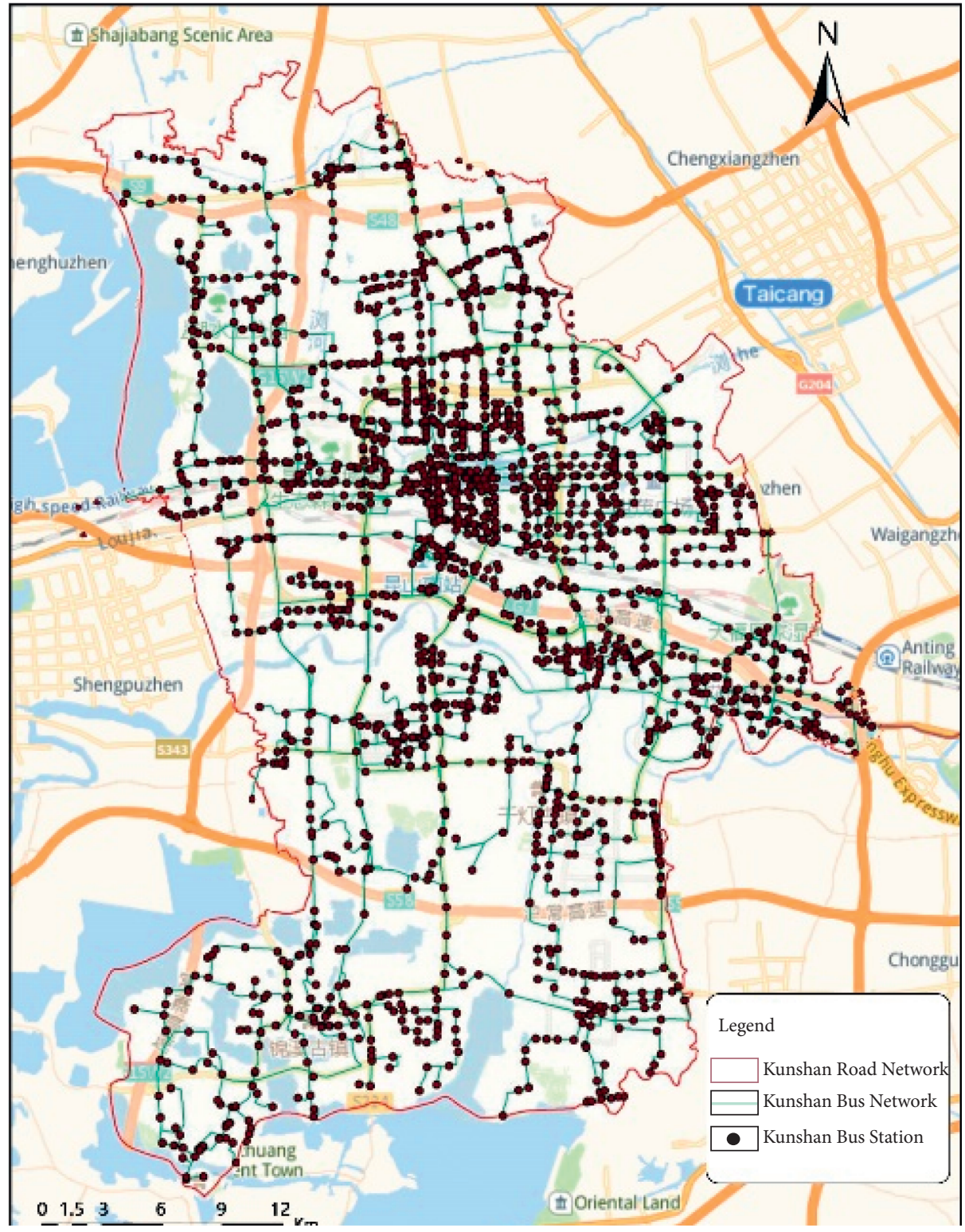

FIGURE 7: Layout of public transport infrastructure.

TABLE 8: Public transport and car accessibility in Kunshan Theil index contribution (\%).

\begin{tabular}{|c|c|c|c|c|}
\hline \multirow{2}{*}{ Region } & \multicolumn{2}{|c|}{ Public transport } & \multicolumn{2}{|c|}{ Cars } \\
\hline & Intra-area & Inter- area & Intra-area & Inter- area \\
\hline Waterfront old town area & 70.59 & 29.41 & 73.38 & 26.62 \\
\hline Eastern vice city & 20.77 & 79.23 & 13.60 & 86.40 \\
\hline Yangcheng Lake area & 24.31 & 75.69 & 21.36 & 78.64 \\
\hline Northern new town & 37.17 & 62.83 & 15.44 & 84.56 \\
\hline Central city & 26.67 & 73.33 & 13.19 & 86.81 \\
\hline Western vice city & 20.00 & 80.00 & 26.38 & 73.62 \\
\hline Southern new town & 13.92 & 86.08 & 1.85 & 98.15 \\
\hline Huaqiao business area & 43.54 & 56.46 & 31.46 & 68.54 \\
\hline
\end{tabular}

Note. The area of the plot indicates the traffic zone.

area represents the difference of accessibility between the control units of the city. For example, although the Theil index of intra-area in Yangcheng Lake area is small, the value of inter- area Theil index of that area is the largest, reaching 0.0274, which indicates that the unbalanced development of public transport is mainly reflected in the level of transport zones. 
4.2.1. Characteristics of the Overall Spatial Distribution of the Theil Index. In terms of the Theil index for the same mode of transport (Table 7), the order of the Theil index values for each district of Kunshan from lowest to highest is central city < southern new town $<$ western vice city $<$ eastern vice city $<$ northern new town $<$ Huaqiao business area $<$ ancient Water Town $<$ Yangcheng Lake area.

The order of car Theil index values from lowest to highest is southern new town $<$ central city $<$ eastern vice city $<$ western vice city $<$ northern new town $<$ Water Town $<$ Yangcheng Lake $<$ Huaqiao business area, so southern new town has the most equitable access to public transport and Huaqiao business area has the least equitable access to public transport.

In terms of the spatial distribution of the Theil index (Figure 6), the fairness of the distribution of public transport and car accessibility tends to decrease spatially from the central city to the peripheral areas, that is, the closer to the central city, the smaller the Theil index value, the smaller the difference in accessibility between the transport zone, and the more equitable the transport zone are to each other.

The layout of public transport infrastructure in Kunshan (Figure 7) reveals that the central city was developed and built earlier, with a well-developed road system and good transport infrastructure, and people can easily reach their destinations by public transport or car. In contrast, only a few transport lines are operating away from the central city, and areas close to the transport lines can travel more conveniently, while areas away from the roads are less accessible, so there is a clear difference in equity.

The Theil index values for public transport and car accessibility in the Huaqiao area are high, but in fact, the road transport infrastructure in the Huaqiao area is already relatively well developed, probably since travel in Huaqiao is so closely linked to Shanghai that it is not possible to determine the destination of travel in the statistics of the internal base stations in Kunshan, thus causing errors in the calculation of accessibility.

4.2.2. Intra- and Inter-Area Characterization of the Theil Index. In terms of the contribution of the public transport and car accessibility Theil indices (Table 8), the contribution of the inter-area variation to the total Theil index is greater than $60 \%$, except for the Water Town ancient town area, indicating that the variation inaccessibility between transport zone is significant. The contribution of the intra-area variation to the total Theil index is greater than $70 \%$ in the Water Town area, which indicates that in the Water Town area, the variation in the accessibility of the base station units within the transport zone is significant, mainly due to the sparse bus line network in the Water Town area, and although each transport zone has line coverage, the base station bus line network coverage within the unit is insufficient and uneven.

The magnitude of the Theil index value between different modes of transport is smaller for public transport than for cars, indicating that the equity of public transport in Kunshan is higher than that of cars, and the difference in the accessibility of public transport trips in each transport zone is smaller than that of car trips. As a public resource, public transport is a service that aims to serve more people, so there will be a greater concern for equity in the siting of bus stops and the setting of bus route networks.

\section{Conclusions}

5.1. Conclusion and Discussion. In this study, the travel time of people in different spaces in the Kunshan city using different modes of transport was simulated using Gaode Map path planning, while accessibility was introduced into the calculation of the Theil index, to carry out a spatial variability analysis of transport equity in the Kunshan city. The research findings of the study are given below:

5.1.1. Public Transport Accessibility Is Weaker than Car Accessibility in Kunshan. The accessibility of public transport in Kunshan is lower than the accessibility of cars, and public transport is at a competitive disadvantage compared to cars. In terms of spatial pattern, the competitive advantage of public transport is mainly concentrated in the central urban area and shows a decreasing distribution pattern from the center to the surrounding areas. This indicates that there are obvious spatial differences in the construction of public transport infrastructure, with the central urban areas having better urban public transport resources. In terms of the relative value of travel time, the ratio of public transport travel time consumption to car travel time consumption fluctuates around 3.51, a large difference from the public transport 1.5 strategy; the service level of public transport still has more room for improvement; and public transport speed is the future development direction.

5.1.2. The Equity of Public Transport in Kunshan Is Better than That of Car Traffic. Although the accessibility of public transport in Kunshan is lower than that of car transport, the equity of public transport is better than that of car traffic. In terms of the overall Theil Index, the Theil Index for public transport is smaller than that for car traffic, so public transport is more equitable than car traffic for commuters. It is a good indication of the rationality of the current layout of public transport stations and bus routes in Kunshan, and the greater emphasis on equity in the planning of the bus network. In the future planning of public transport infrastructure, the efficiency of public transport should be considered based on fairness to balance equity and efficiency.

5.1.3. The Accessibility of Public Transport in the Kunshan City Is Significantly Different among Different Units, and the Spatial Distribution of Transport Facilities Is Uneven. The difference in equity between public transport and car transport in Kunshan is caused by the difference in accessibility levels between the transport zones. In terms of the Theil index for the decomposition of public transport and car traffic, the inter-area unit contribution of both modes of transport is greater than the intra-area unit contribution (except for the Water Town area), so inequity is mainly found between transport zones. In the case of Water Town, 
the inequity is significant within the base units. The division of transport zone in Kunshan is mainly based on the boundaries of roads or natural waterways. The scale of the transport zone gradually increases from the central city to the periphery. The central city and its peripheral transport zone are comparatively small, so the transport infrastructure within each transport zone varies considerably, with significant inter-area differences. The transport zones in the Water Town area are large, and each district is covered by a network of bus lines, with little difference in transport infrastructure between the districts, but the network of lines within the districts is sparse and unevenly distributed, so the differences are apparent.

5.2. Recommendations. Based on the findings of the study, the following measures are proposed from the perspective of planning, construction and management and regulatory policy.

\subsubsection{Enhancing the Competitiveness of Public Transport to Promote Equity in Transport Modes}

(1) Internalization Policy of External Cost of Cars. Externalities are the main reason for the inequity of car travel. A large number of car trips lead to road congestion and air pollution, which have an unfair impact on people with other modes of transportation. Therefore, the internalization of external cost is the main means to solve a large number of cars, and the most common means are regulation and taxation. Figures 4 and 5 show the spatial distribution of accessibility and fairness in Kunshan. It is necessary for the central city and Huaqiao business area to increase congestion charges and sewage charges to increase travel costs to suppress the demand for car travel.

(2) Bus Priority Development Strategy. As the understanding of the right of way and its implications for transport grows, so does the urgent need to build bus lanes in the central city and Huaqiao business area in Kunshan and establish relevant laws and regulations to ensure priority of public transportation. A safe and comfortable bus travel environment, convenient transfer facilities, and reasonable fare mechanism can also attract more citizens to choose public transport, which can effectively promote the substantive priority of public transport and jointly promote the fair development of the whole area of transport.

\subsubsection{Allocating Traffic Resources Rationally to Promote Regional Equity}

(1) Build a Perfect BRT Network to Promote Fairness between City Districts. With the development of the city, there will be a lot of commuting between the urban core area and the surrounding areas. The conventional bus cannot meet the rapid and large commuting demand between the large areas, so it is necessary to build the rapid bus corridor to connect the urban areas and groups closely. Considering the existing road network, the expressway based on the main roads should be established to link the surrounding districts and avoid traffic congestion caused by cross-district commutes through the urban core areas in the surrounding districts. In addition, relying on G2 Expressway and central South Line, a bus corridor connecting west subcity, east subcity, urban core area, and Huaqiao business area will be established to run through the east and west. The government should also establish rapid transit corridors relied on S224 Road to link the north and south. Finally, a BRT skeleton network will be formed that connects the surrounding areas with the core area, north, south, east, and west. The integration of traffic networks will greatly promote the fairness of the whole traffic in the region.

(2) Build a Full-Covered Bus Network to Narrow the Accessibility Gap within the Base Station Units. The unfairness between urban districts mainly comes from the accessibility gap between base station units. Therefore, improving the bus network in each district to improve the reasonable layout of the public transportation network and the coverage of bus stops is an effective means to improve the accessibility gap between base station units. As shown in Figure 7, the traffic network between the urban center area, the northern new town, the eastern vice city, and the western vice area has been basically connected, while the resources at the junction of the southern new town, the western vice city, the urban center area, and the eastern vice area are sparse. It is because of drainage group partition. This is because the river group partition, and the accessibility of both sides of the river can be improved by building bridges and improving the transportation network along the river. At the same time, the surrounding districts need to establish convenient transfers with BRT transportation facilities. With BRT stations as the core, a conventional bus connection system within the region should be established to improve the bus network and station layout so as to achieve full coverage of the bus network. At present, the urban center area and Huaqiao business area, which have relatively perfect transportation infrastructure, need to further improve the operation efficiency of the bus network and establish a more punctual and reliable bus operation system through intelligent means, such as increasing the frequency and shortening the departure time during peak hours, to ensure the toughness of bus operation and maximize the efficiency of public transport.

5.3. Research Highlights and Limitations. Mobile phone data is a new approach to urban travel research that can compensate for the high volume, high cost, and inadequate sampling rate of traditional residential survey data. The innovation of this paper is to use mobile phone signaling data to group the travelers in the Kunshan city according to the spatial structure, then simulate and calculate the accessibility values of public transport and cars including the traveler population factor, and use the Theil index to study the difference of accessibility between different spaces and different modes of transport. Mobile phone data can truly reflect the travel behavior of residents. The results of accessibility can be more accurate and appropriate to the actual situation. The results can be further used in other research 
areas, such as urban forms and other factors affecting urban public transportation travel, evaluation and comparison of transportation or urban planning programs, and research on transportation location, land prices, travel behavior and so on in sociology, geography, economics, and so on.

In this study, as processed mobile phone data does not involve travel OD across municipal boundaries, this method is not very applicable to areas with a large cross-regional travel population. In other words, all the data screened in this study through mobile phone signaling data are internal travel data of the Kunshan city and do not involve samples of cross-city travel, and the results of this study are not representative for areas like Huaqiao where a large number of commuter travel destinations are in Shanghai. Therefore, the results of this paper are not sufficiently interpreted for the Huaqiao area and need to be further explored in conjunction with the Shanghai base station data.

\section{Data Availability}

The travel time consumption data were taken from the application programming interface (API) of Gaode Map. Mobile phone signaling data were taken from China Mobile Communications Corporation (CMCC).

\section{Conflicts of Interest}

The author declares that there are no conflicts of interest regarding the publication of this paper.

\section{Acknowledgments}

This research work was supported by Science and Technology Projects of District Qixia, Nanjing, China, named Intelligent transportation big data analysis and planning decision platform development (2019-2021).

\section{References}

[1] J. Huang, Y. Song, W. Gao, and Y. Chen, "Lessons from New York's inclusive urban planning experience for China," Urban Development Research, vol. 26, no. 6, pp. 45-51+86, 2019, [In China].

[2] M. Zhang, "A study on the equitable supply and planning allocation methods of public service facilities in global cities taking New York, London and Tokyo as examples," International Urban Planning, vol. 32, no. 6, pp. 69-76, 2017.

[3] S. L. Handy and D. A. Niemeier, "Measuring accessibility: an exploration of issues and alternatives," Environment and Planning A: Economy and Space, vol. 29, no. 7, pp. 1175-1194, 1997.

[4] D. A. Niemeier, "Accessibility: an evaluation using consumer welfare,” Transportation, vol. 24, no. 4, pp. 377-396, 1997.

[5] K. T. Geurs and B. Van Wee, "Accessibility evaluation of landuse and transport strategies: review and research directions," Journal of Transport Geography, vol. 12, no. 2, pp. 127-140, 2004.

[6] B. Alam, G. Thompson, and J. Brown, "Estimating transit accessibility with an alternative method: evidence from broward county, Florida, transportation research record," Journal of the Transportation Research Board, no. 2144, pp. 62-71, 2010.
[7] I. Minocha, P. S. Sriraj, P. Metaxatos, and P. Thakuriah, "Analysis of transit quality of service and employment accessibility for the Greater Chicago, Illinois, Region," Transportation Research Record: Journal of the Transportation Research Board, vol. 2042, no. 1, pp. 20-2, 2008.

[8] H. J. Miller, "Measuring space-time accessibility benefits within transportation networks: basic theory and computational procedures," Geographical Analysis, vol. 31, no. 1, pp. 187-212, 1999.

[9] T. Neutens, T. Schwanen, F. Witlox, and P. De Maeyer, "Equity of urban service delivery: a comparison of different accessibility measures," Environment and Planning A: Economy and Space, vol. 42, no. 7, pp. 1613-1635, 2010.

[10] A. Owen and D. M. Levinson, "Modeling the commute mode share of transit using continuous accessibility to jobs," Transportation Research Part A: Policy and Practice, vol. 74, pp. 110-122, 2015.

[11] D. O'Sullivan, A. Morrison, and J. Shearer, "Using desktop GIS for the investigation of accessibility by public transport: an isochrone approach," International Journal of Geographical Information Science, vol. 14, no. 1, pp. 85-104, 2000.

[12] K. Witten, D. Exeter, and A. Field, "The quality of urban environments: mapping variation in access to community resources," Urban Studies, vol. 40, no. 1, pp. 161-177, 2003.

[13] K. Witten, J. Pearce, and P. Day, "Neighbourhood destination accessibility Index: a GIS tool for measuring infrastructure support for neighbourhood physical activity," Environment and Planning A: Economy and Space, vol. 43, no. 1, pp. 205-223, 2011.

[14] M. Ben-Akiva and S. R. Lerman, "Disaggregate travel and mobility-choice models and measures of accessibility," in Proceedings of the 3rd International Conference on Behavioral Travel Modelling, D. A. Hensher and P. R. Stopher, Eds., pp. 654-679, Croom-Helm, London, UK, 1979.

[15] T. Yigitcanlar, N. Sipe, R. Evans, and M. Pitot, "A GIS-based land use and public transport accessibility indexing model," Australian Planner, vol. 44, no. 3, pp. 30-37, 2007.

[16] M. W. Horner and A. T. Murray, "Spatial representation and scale impacts in transit service assessment," Environment and Planning B: Planning and Design, vol. 31, no. 5, pp. 785-797, 2004.

[17] Q. Shen, "Location characteristics of inner-city neighborhoods and employment accessibility of low-wage workers," Environment and Planning B: Planning and Design, vol. 25, no. 3, pp. 345-365, 1998.

[18] T. Yigitcanlar, N. Sipe, R. Evans, and M. Pitot, "A GIS-based land use and public transport accessibility indexing model," Australian Planner, vol. 44, no. 3, pp. 30-37, 2007.

[19] E. Papa and L. Bertolini, "Accessibility and transit-oriented development in European metropolitan areas," Journal of Transport Geography, vol. 47, pp. 70-83, 2015.

[20] D. O'Sullivan, A. Morrison, and J. Shearer, "Using desktop GIS for the investigation of accessibility by public transport: an isochrone approach," International Journal of Geographical Information Science, vol. 14, no. 1, pp. 85-104, 2000.

[21] C. Cheng and A. W. Agrawal, "TTSAT: a new approach to mapping transit accessibility," Journal of Public Transportation, vol. 13, no. 1, p. 4, 2010.

[22] C. M. Burns and A. D. Inglis, "Measuring food access in Melbourne: access to healthy and fast foods by car, bus and foot in an urban municipality in Melbourne," Health \& Place, vol. 13, no. 4, pp. 877-885, 2007. 
[23] H. B. Jiang, J. G. Xu, and Y. Qi, "Impact of Beijing-Shanghai high-speed railway on land accessibility of regional central cities," Journal of Geography, p. 10, 2010.

[24] Yi Qi, Planning Support Systems and Urban Public Transport, Southeast University Press, Nanjing, China, 2010.

[25] I. Benenson, E. Ben-Elia, Y. Rofé, and D. Geyzersky, "The benefits of a high-resolution analysis of transit accessibility," International Journal of Geographical Information Science, vol. 31, no. 2, pp. 213-236, 2017.

[26] E. W. Dijkstra, "A note on two problems in connexion with graphs," Numerische Mathematik, vol. 1, no. 1, pp. 269-271, 1959.

[27] G. Boisjoly, A. I. Moreno-Monroy, and A. El-Geneidy, "Informality and accessibility to jobs by public transit: evidence from the são paulo metropolitan region," Journal of Transport Geography, vol. 64, pp. 89-96, 2017.

[28] A. I. Moreno-Monroy, R. Lovelace, and F. R. Ramos, "Public transport and school location impacts on educational inequalities: insights from São Paulo," Journal of Transport Geography, vol. 67, pp. 110-118, 2018.

[29] A. Singleton, "A GIS approach to modelling CO2 emissions associated with the pupil-school commute," International Journal of Geographical Information Science, vol. 28, no. 2, pp. 256-273, 2014.

[30] Y. Chen, A. Rajabifard, and J. Day, "An advanced web API for isochrones calculation using OpenStreetMap data," Lecture Notes in Geoinformation and Cartography, pp. 185-205, 2017.

[31] L. Jiang, H. Z. Alex, P. Kumar, and P. John, "Equity in job accessibility and environmental quality in a segmented housing market: the case ofgreater London," Journal of Transport Geography, vol. 90, 2021.

[32] G. Sharma and R. Patil Gopal, "Public transit accessibility approach to understand the equity for public healthcare services: a case study of Greater Mumbai," Journal of Transport Geography, vol. 94, 2021.

[33] A. Ermagun and N. Tilahun, "Equity of transit accessibility across Chicago," Transportation Research Part D, vol. 86, 2020.

[34] R. H. M. Pereira, Tim Schwanen, and D. Banister, "Distributive justice and equity in transportation," Transport Reviews, vol. 37, no. 2, 2017.

[35] L. Wu, X. Zhu, and H. Jiang, "A review of foreign theoretical approaches to traffic equity analysis," Planner, vol. 30 , no. 11, pp. 108-113, 2014, [In China].

[36] T. Litman, "Evaluating transportation equity," World Transport Policy \& Practice, 2002.

[37] M. Garrett and B. Taylor, "Reconsidering social equity in public transit," Berkeley planjournal, no. 1, pp. 6-27, 1999.

[38] Z. Lv, Evaluation of Urban Traffic Fairness and Countermeasures, pp. 1-23 Chang'an University, Xi'an, China, 2005, [In China].

[39] J. Walker, "Purpose-driven public transport: creating a clear conversation about public transport goals," Journal of Transport Geography, vol. 16, no. 6, 2008.

[40] W. Yang, "Experimenting with transport equity," Comprehensive Transport, no. Z1, pp. 13-16, 2006.

[41] Y. Li, Transformation of the Concept of Public Transport Priority and Evaluation Methods from the Perspective of Equity and accessibility[D], Nanjing University, Nanjing, China, 2018.

[42] G. Currie, "Quantifying spatial gaps in public transport supply based on social needs," Journal of Transport Geography, vol. 18, no. 1, 2008.
[43] G. Kiarash, E. Murat, and D. Nima, "Exploring equity in public transportation planning using smart card data," Sensors, vol. 21, no. 9, 2021.

[44] J. Shi, Y. Lang, H. Qian, and X. Ying, "Measurement perspective and model description of transportation fairness," Journal of Railway Engineering, no. 1, pp. 97-101, 2009, [In China].

[45] Y. Lang, J. Shi, and H. Lu, "Evaluation method of investment fairness of road facilities project," Journal of Tsinghua University, no. 9, pp. 1162-1165, 2005, [In China].

[46] Z. Chen and X. Li, "Unobserved heterogeneity in transportation equity analysis: evidence from a bike-sharing system in southern Tampa," Journal of Transport Geography, vol. 91, 2021.

[47] Z. Li, R. Shen, N. Hu et al., "Equality of public transit connectivity: the influence of mass rapid transit services on individual buildings for Singapore," Transportation Business: Transport Dynamics, vol. 7, no. 1, 2019.

[48] Q. Yang and J. Xu, "Construction of a fairness evaluation model of public service facilities based on gravitational accessibility," Planner, vol. 31, no. 7, pp. 96-101, 2015, [In China].

[49] Q. Wang and Q. Yu, "A theoretical discussion on transport equity," Comprehensive Transportation, no. 8, pp. 5-9, 2007, [In China].

[50] M.-L. Wu and K. Cao, "Quantitative evaluation of transportation equity based on Gini coefficient," Transportation Technology and Economy, vol. 13, no. 1, pp. 86-89, 2011, [In China].

[51] Y. Niu, "Analysis of regional economic development differences in Gansu Province based on the Theil Index," Business Economics, no. 11, pp. 27-29, 2013, [In China].

[52] Y. Shi, "Measurement and evaluation of unevenness of social security expenditure in less developed regions in the west-Xinjiang as an example," Economic Geography, vol. 35, no. 6, pp. 161-167, 2015, [In China].

[53] L. Qin and L. Huang, "A study on the fairness of health resource allocation in Chongqing based on the Theil index," China Health Management, vol. 30, no. 11, pp. 844-847, 2013, [In China].

[54] Y. O. Liu, "Assessment of the level of equalization of basic medical and health services in urban and rural areas--an analysis based on the Theil index," Rural Economy and Technology, vol. 29, no. 17, pp. 252-254, 2018, [In China].

[55] J. Sun and Q. Wen, "Analysis of the fairness of health resource allocation in Jiangsu Province based on concentration index and Thiel index," Modern Hospital Management, vol. 14, no. 5, pp. 41-43, 2016, [In China].

[56] C. Lv and X. Qian, "Study on the spatial imbalance of transportation infrastructure and interconnection policies of the New Silk Road Economic Belt," Journal of Shanghai University of Finance and Economics, vol. 17, no. 2, pp. 4453+85, 2015, [In China].

[57] B. Santos, A. Antunes, and J. Eric, "Miller. Integrating equity objectives in a road network design model," Transportation Research Record, vol. 2089, no. 1, 2008.

[58] F. Tao and J. Zhang, "Multicriteria evaluation on accessibilitybased transportation equity in road network design problem," Journal of Advanced Transportation, vol. 48, no. 6, 2014.

[59] M. G. Demissie, S. Phithakkitnukoon, and L. Kattan, "Trip distribution modeling using mobile phone data: emphasis on 
intra-zonal trips," IEEE Transactions on Intelligent Transportation Systems, 2018.

[60] M. Batty, Urban Modelling: Algorithms, Calibrations, Predictions, Cambridge University Press, Cambridge, UK, 2010. 